\title{
Urologia onkologiczna — co zmieniło się w ciągu ostatnich 25 lat?
}

\author{
Paweł Stajno, Paweł Wiechno, Tomasz Demkow
}

\begin{abstract}
W ostatnim ćwierćwieczu obserwuje się istotny postęp w uroonkologii; niektóre elementy przedstawiono w poniższym przeglądzie piśmiennictwa, uzupełniając je danymi epidemiologicznymi.

Wieloparametryczny rezonans magnetyczny pozwala na lepsze wykrywania małych raków prostaty i na znacznie precyzyjniejszą ich resekcję. Kolejnym usprawnieniem jest badanie rezonansu z wykorzystaniem ultra małych cząstek tlenku żelaza, szczególnie przydatne w wykrywaniu mikroprzerzutów do regionalnych węzłów chłonnych. Wprowadzono nowy marker molekularny prostate cancer gene 3 specyficzny dla komórek raka prostaty. Zasadę odroczonego leczenia - watchful waiting zastąpiono strategią aktywnego nadzoru — active surveillance. Postęp w leczeniu napromienianiem chorych na raka prostaty to wynik wprowadzenia trójwymiarowej radioterapii konformalnej, radioterapii z wykorzystaniem techniki intensywnej modulacji wiązki, radioterapii sterowanej obrazem, hypofrakcjonacji, radioterapii stereotaktycznej i protonoterapii.

Pomimo wprowadzenia nowych metod wykrywania raka pęcherza, jak diagnostyka fotodynamiczna i obrazowanie w wąskim paśmie światła, wyniki leczenia pozostają złe. Dzięki postępowi technik diagnostycznych ponad połowa guzów nerki wykrywana jest przypadkowo, podczas postępowania z innych wskazań medycznych. Chorzy ci najczęściej leczeni są częściową nefrektomią. Doskonałe wyniki leczenia guzów jądra powodują, że powiększa sie populacja młodych, wyleczonych mężczyzn, co z kolei stwarza nowe problemy o charakterze społecznym (np. zagadnienie rozrodczości).
\end{abstract}

\section{Urological oncology: what has changed in the recent 25 years?}

A considerable progress in the diagnosis and treatment of urinary tract cancers in the last 25 years is observed. A short review of this process is presented, together with the epidemiological data on most frequent cancer locations. Multiparametric magnetic resonance allows for an improved detection of small prostate cancers and more precise resection; this may be combined with ultrasmall superparamagnetic particles of iron oxide-enhanced and diffusion-weighted magnetic resonance imaging. Prostate cancer gene 3 (PCA3) is a new prostate cancer cell-specific marker. A "watchful waiting" method of deferred treatment is now substituted by "active surveillance". 3-Dimensional Conformal Radiation Therapy, Intensity Modulated Radiation Therapy, Image-Guided Radiation Therapy and other techniques facilitate more precise and dose-increased prostate cancer irradiation. Despite the implementation of new techniques in bladder cancer detection, like photodynamic diagnosis and narrow band imaging, overall treatment results remain poor. Due to the progress of imaging techniques c. 50\% of new renal cancer cases are now randomly detected and may be treated by nephron sparing surgery. The population of young men, cured definitely from testicular cancer, due to the excellent overall treatment results, is increasing; this requires more attention attributed to their social (i.e. reproductive) problems.

Słowa kluczowe: rak prostaty, rak nerki, rak pęcherza, rak jądra, rozpoznawanie, leczenie, postęp Key words: prostate cancer, renal cancer, bladder cancer, testicular cancer, progress 


\section{Wstęp}

Ostatnie ćwierćwiecze przyniosło istotny postęp w rozpoznawaniu i leczeniu nowotworów układu moczowo-płciowego męskiego. Nowoczesne metody obrazowania, rozwój technik chirurgii małoinwazyjnej oraz nowe leki przyczyniły się do poprawy wyników leczenia. Niniejsze opracowanie ukazuje wybrane zmiany w diagnostyce i leczeniu najczęstszych nowotworów układu moczowego, jakie dokonały się w okresie ostatnich 25 lat.

\section{Gruczolakorak gruczołu krokowego Dane epidemiologiczne}

Gruczolakorak gruczołu krokowego jest najczęściej rozpoznawanym nowotworem układu moczowo-płciowego, a zarazem najczęstszym nowotworem złośliwym u mężczyzn powyżej 70 roku życia w Europie [1]. W Polsce w latach 1980-2013 nastąpił ponad siedmiokrotny wzrost częstości zachorowań - z 1731 przypadków w 1980 roku do 12162 w 2013 [2]. W 2013 roku rak ten był przyczyną zgonu u prawie 5-krotnie większej liczby mężczyzn w porównaniu do roku 1965 (odpowiednio: 4281 zgonów w stosunku do 895) [1, 2].

Obserwowany wzrost wykrywalności raka prostaty z pewnością wynika z wydłużenia średniego okresu przeżycia, łatwiejszego dostępu do wydajniejszych metod diagnostycznych (PSA, TRUS, mpMRI), poprawy wiedzy społeczeństwa na temat zagrożeń związanych z rozpoznawaniem nowotworów w zaawansowanym stadium rozwoju i lepszej organizacji służby zdrowia. Standaryzowany wskaźnik pięcioletnich przeżyć w populacji chorych, u których wykryto ten nowotwór w okresie 1995-2009, wzrósł o 20\% [1, 2].

\section{Rozpoznanie}

Diagnostyka raka prostaty przed 25 laty polegała na palpacyjnej ocenie konsystencji gruczołu krokowego oraz oznaczeniu stężenia PSA. Gdy badanie fizykalne budziło podejrzenie obecności nowotworu, pobierano wycinki z narządu pod kontrolą ultrasonografii przezodbytniczej (TRUS). Obecnie dysponujemy szeregiem dodatkowych badań, które precyzyjniej określą podstawowe cechy nowotworu: zaawansowanie miejscowe (cecha $\mathrm{T}$ ), stan regionalnych węzłów chłonnych (cecha N) oraz obecność przerzutów odległych (cecha M).

Przełomem w diagnostyce obrazowej prostaty jest wieloparametryczny rezonans magnetyczny (mpMRI). Badanie, zwłaszcza z wykorzystaniem nowoczesnych 3-teslowych aparatów, cechuje się wysoką czułością w zakresie wykrywania gruczolakoraka o wysokim stopniu złośliwości histologicznej (Gleason score $\geq 7$ ). Wykonanie tego badania jest zalecane u mężczyzn, u których mimo podejrzenia raka nie udało się wykazać obecności jego komórek w wycinkach pobranych w trakcie „standardowej” biopsji narządu. Dostępne oprogramowanie pozwala dokonać fuzji obrazów USG i rezonansu magnetycznego, co znacznie ułatwia wybranie miejsca, w którym prawdopodobieństwo uzyskania reprezentatywnego materiału do badania mikroskopowego jest wysokie [3, 4]. Ponadto mpMRI, dzięki precyzyjnemu umiejscowieniu guza, pozwala zaplanować usunięcie narządu w taki sposób, aby zostały oszczędzone pęczki naczyniowo-nerwowe odpowiedzialne za prawidłowe wzwody prącia.

Od niedawna w Polsce dostępna jest pozytronowa tomografia emisyjna (PET-CT). W raku stercza badanie to, z wykorzystaniem choliny znakowanej węglem ${ }^{11} \mathrm{C}$, znalazło zastosowanie w ustalaniu przyczyn wznowy biochemicznej po leczeniu radykalnym [5].

Do najnowszych osiągnięć w obrazowaniu nowotworu stercza należy zaliczyć: badanie PET-CT, które wykorzystuje zjawisko łączenia się ligandu znakowanego ${ }^{68}$ galem z antygenem błony komórek stercza (PSMA — prostate-specific membrane antigen), oraz badanie MRI z wykorzystaniem ultra małych cząstek tlenku żelaza (USPIO). Badania te wykorzystywane są do wykrywania mikroprzerzutów do regionalnych węzłów chłonnych $[6,7]$.

Od początku lat dziewięćdziesiątych ubiegłego stulecia rutynowo oznacza się w surowicy PSA, który jest markerem swoistym dla narządu, natomiast nie jest specyficzny dla nowotworu stercza. Kilka lat temu wprowadzono nowy marker molekularny PCA3 (prostate cancer gene 3), specyficzny dla komórek raka stercza, który oznacza się w osadzie moczu po masażu stercza. Wysokie miano PCA 3 koreluje ze zwiększonym prawdopodobieństwem wykrycia raka prostaty [8].

\section{Leczenie}

Postęp w leczeniu chorych na raka prostaty jest doskonałym przykładem, jak zmieniła się uroonkologia w ciągu ostatnich lat. Jeszcze 25 lat temu jedyną formą leczenia „odroczonego" (deferred treatment) było postępowanie zwane watchful waiting. Polegało ono na obserwacji chorego do momentu, gdy występowały objawy choroby, po czym rozpoczynano leczenie o założeniu paliatywnym. Taki sposób postępowania proponowano mężczyznom, którzy z różnych względów nie kwalifikowali się do leczenia radykalnego.

Nową formą leczenia „odroczonego" jest strategia „,aktywnego nadzoru" (active surveillance), przeznaczona dla odmiennej grupy pacjentów. Do aktywnej obserwacji kwalifikują się chorzy z grupy o małym ryzyku progresji choroby, u których przewidywany czas przeżycia przekracza 10 lat. Celem tego postępowania jest uchronienie od powikłań występujących po radykalnym leczeniu (np. zaburzeń erekcji, nietrzymania moczu) grupy chorych na raka „klinicznie nieistotnego" [3].

Rozwój chirurgii małoinwazyjnej oraz wykorzystującej roboty pozwala w nowoczesnej urologii wykonywać wszystkie standardowe zabiegi chirurgiczne z wykorzystaniem tych technik. Polska jest niestety jednym z nielicznych krajów Europy, gdzie chirurdzy nie mają doświadczenia w stosowaniu robotów. 
Dwadzieścia pięć lat temu radykalne leczenie operacyjne było proponowane jedynie chorym na nowotwór ograniczony do narządu (cT1-2 N0). Obecnie wskazania do radykalnej prostatektomii uległy rozszerzeniu o grupę mężczyzn chorych na raka miejscowo zaawansowanego (cT3a cN0) [3]. W niektórych ośrodkach naukowych, w ramach badań klinicznych, wykonuje się radykalną prostatektomię nawet u chorych na „raka z niewielką liczbą przerzutów”.

Radioterapia jest od lat uznaną metodą w leczeniu raka prostaty. Przed wprowadzeniem nowoczesnych metod, takich jak: trójwymiarowa radioterapia konformalna (3D-CRT -3-Dimensional Conformal Radiation Therapy), radioterapia z wykorzystaniem techniki intensywnej modulacji wiązki (IMRT - Intensity Modulated Radiation Therapy), radioterapia sterowana obrazem (IGRT — Image-Guided Radiation Therapy), hypofrakcjonacja, radioterapia stereotaktyczna czy protonoterapia - w leczeniu raka stercza stosowano dawkę łączną ok. 64 Gy. Obecnie możliwe jest bezpieczne stosowanie dawek powyżej $80 \mathrm{~Gy}$, co istotnie wpłynęło na poprawę odległych wyników leczenia [3, 9]. Radioterapia znajduje także zastosowanie jako leczenie uzupełniające (napromienienie na lożę pooperacyjną) po leczeniu chirurgicznym w przypadku wysokiego ryzyka wznowy miejscowej [3].

Brachyterapia stała się jedną z metod radykalnego leczenia, obecnie zarezerwowaną dla wybranych chorych na raka o małym ryzyku progresji.

Poza leczeniem chirurgicznym i radioterapią w ostatnich latach pojawiły się nowe metody niszczenia nowotworu ograniczonego do narządu (focal treatment), wykorzystujące np. zogniskowaną falę ultradźwiękową (HIFU - High Intensity Focused Ultrasound) czy zjawisko uszkodzenia komórki nowotworowej w niskich temperaturach (CSAP — Cryosurgical Ablation of the Prostate) [10, 11].

Należy wymienić również szereg leków, które wprowadzono w leczeniu chorych na rozsianą chorobę nowotworową. Nowymi lekami obniżającymi poziom androgenów są antagoniści LH-RH (degarelix), które w przeciwieństwie do agonistów nie wymagają stosowania antyandrogenów w celu prewencji zespołu flare-up. Obecnie dostępna jest postać leku do comiesięcznego podawania (w przypadku agonistów dysponujemy postaciami do podawania w odstępach 3-i 6-miesięcznych).

W związku z lepszym zrozumieniem wpływu gospodarki hormonalnej na postęp choroby wprowadzono pojęcie "opornego na kastrację raka stercza" (CRPC — castration resistant prostatecancer) w miejsce dotychczas stosowanej nazwy „hormonooporny rak stercza”. Do nowych leków, bardziej skutecznych w tej fazie choroby, należy octan abirateronu, który jest doustnym, niesteroidowym inhibitorem cytochromu CYP17. Lek blokuje produkcję testosteronu zarówno w jądrach, nadnerczach, jak i w tkance nowotworowej [3]. Kolejnym lekiem jest enzalutamid, który jest antyandrogenem wykazującym około pięciokrotnie wyższe powino- wactwo do receptora androgenowego niż bikalutamid [3]. Leki te poprawiają przeżycie całkowite zarówno u chorych jeszcze nieotrzymujących chemioterapii, jak i u mężczyzn z progresją po chemioterapii docetakselem (abirateron — badanie COU-AA-302 oraz COU-AA-301 [12, 13], enzalutamid — badanie PREVAIL i AFFIRM) $[14,15]$.

W leczeniu chorych na CRPC stosowane są również cytostatyki. Docetaksel jest obecnie standardowym lekiem w chemioterapii pierwszego rzutu w leczeniu tej grupy chorych. W badaniach klinicznych SWOG 99 -19 i TAX 327 udowodniono poprawę przeżycia w porównaniu z terapią mitoksantronem z prednizolem [16, 17]. W leczeniu drugiego rzutu w CRPC poza abirateronem i enzalutamidem możliwe jest zastosowanie chemioterapii drugiego rzutu kabazytakselem [3].

Kolejnym sposobem leczenia chorych na CRPC jest autologiczna immunoterapia o nazwie Sipuleucel T, która została dopuszczona przez FDA do stosowania na terenie USA w 2010 r. po przedstawieniu badań klinicznych, które wykazały przedłużenie przeżycia całkowitego [18].

U większości chorych na CRPC występują przerzuty do kości, które są przyczyną bólów i/lub złamań. Lekiem wydłużającym czas do wystąpienia powikłań kostnych w grupie chorych na CRPC jest denosumab. Lek ten jest ludzkim monoklonalnym przeciwciałem przeciwko RANKL (kluczowy mediator wpływający na funkcje osteoklastów) [19]. Lekiem zalecanym u chorych z przerzutami do kości w fazie oporności na kastrację jest alfaradin (izotop Ra-223). Działanie tego leku u chorych na CRPC jest wybitnie miejscowe. Zdeponowany w kości izotop jest źródłem promieniowania alfa, które cechuje się bardzo niewielkim obszarem działania. Dlatego toksyczność (zwłaszcza hematologiczna) alfaradinu jest zbliżona do placebo. Alfaradin znamiennie statystycznie zmniejsza bóle kostne, poprawia jakość życia oraz wydłuża przeżycie ogólne. Należy zaznaczyć, iż nie jest to lek o działaniu przeciwbólowym w przeciwieństwie do poprzednio stosowanych izotopów, gdyż nie niszczy zakończeń bólowych. Działanie przeciwbólowe jest pochodną odpowiedzi terapeutycznej. Lek wywiera korzystne działanie u chorych zarówno przed chemioterapią docetakselem, jak i po takim leczeniu [20].

\section{"Overdiagnosis" $i$ „,overtreatment"}

Problemem zarówno w USA, jak i w Europie pozostaje zjawisko overdiagnosis i overtreatment - diagnozowanie i leczenie mężczyzn, którzy nie odniosą korzyści z takiego postępowania z powodu powolnego rozwoju choroby (nieistotny klinicznie nowotwór). U tych mężczyzn nie wystąpią objawy choroby, a nowotwór nie będzie przyczyną zgonu. Na początku XXI wieku nie potrafimy przewidzieć, u którego z mężczyzn rak będzie przyczyną zgonu, a u którego - pozostanie nieistotny klinicznie. Konsekwencją niemożności przewidzenia rozwoju naturalnego nowotworu u konkret- 
nego mężczyzny są powikłania spowodowane niepotrzebnym leczeniem radykalnym, które istotnie pogarszająjakość życia, jak nietrzymanie moczu, impotencja, bezpłodność, zwężenie cewki moczowej, szereg powikłań wywołanych radioterapią. Corocznie w USA i Europie rejestruje się kilkaset tysięcy nowych zachorowań na raka stercza (w USA w 2015 r. - 220 800, w Europie w 2012 r._- 399 964) [21, 22], z czego u 50\% chorych (często młodych, będących u szczytu swoich możliwości życiowych) wykonuje się niepotrzebnie leczenie radykalne, którego ujemne skutki pozostają do końca życia.

Największym badaniem klinicznym oceniającym rolę badania przesiewowego w populacji mężczyzn w Europie jest ERSPC (European Randomized Study of Screening for Prostate Cancer). Jest to badanie wieloośrodkowe, randomizowane, którego celem jest ocena wpływu oznaczania PSA na śmiertelność z powodu raka prostaty u mężczyzn w wieku 55-69 lat. Po 13 latach prowadzenia badania zaobserwowano zmniejszenie śmiertelności o 21\% w grupie uczestniczącej w badaniu przesiewowym; po uwzględnieniu i usunięciu danych fałszujących (non-complience) — różnica ta wzrosła do 29\%. Wykazano również, iż dla zapobieżenia zgonowi jednego mężczyzny z powodu raka stercza w czasie trwania badania klinicznego ERSPC konieczne było przebadanie 781 mężczyzn (NNS - numberneeded to screen), a następnie przeprowadzenie leczenia 27 mężczyzn z tej grupy (NNT - number needed to treat). Po 9 i 11 latach powyższe dane przedstawiały się następująco: NNS — odpowiednio 1410 i 979, NNT — odpowiednio 48 i 35.

Mimo tych zachęcających wyników autorzy sugerują, że konieczna jest dalsza ocena niekorzystnych następstw związanych z wprowadzeniem populacyjnego oznaczenia stężenia PSA i próba ich ograniczenia [23].

Drugim badaniem oceniającym skutki przeprowadzania badania przesiewowego w grupie wybranych mężczyzn jest badanie kliniczne o nazwie PLCO (Prostate Lung Colorectal and Ovary screening trial), przeprowadzone w USA. Po 13 latach badacze stwierdzili, że nie ma statystycznie istotnej różnicy w liczbie zgonów spowodowanych nowotworem miedzy grupą mężczyzn, u których co 12 miesięcy oceniano gruczoł krokowy per rectum i oznaczano PSA, i grupą kontrolną (skrining oportunistyczny) [24].

Aktualne wytyczne EAU zalecają zindywidualizowaną strategię postępowania u mężczyzn należących do grupy wysokiego ryzyka wystąpienia raka prostaty. Każdy mężczyzna w dobrym stanie ogólnym i przewidywanym przeżyciu co najmniej 10-15 lat powinien uzyskać pełne informacje o obecnym stanie wiedzy na temat overdiagnosis i overtreatment [3].

\section{Podsumowanie}

- w Polsce obserwujemy stały wzrost liczby zachorowań oraz zgonów z powodu raka stercza,

- coraz większą liczbę mężczyzn leczymy niepotrzebnie,
- brakjest, „twardych danych",które byjednoznacznie precyzowały rolę i sposób przeprowadzania badań przesiewowych,

- dysponujemy nowymi metodami obrazowania morfologicznego i metabolicznego gruczolakoraka stercza,

- małoinwazyjne metody leczenia chirurgicznego weszły na stałe do codziennej praktyki klinicznej,

- nastąpiła istotna poprawa wyników leczenia z użyciem radioterapii z pól zewnętrznych,

- w „,bogatych" społeczeństwach chorzy w stadium uogólnienia mają dostęp do leków znamiennie przedłużających OS oraz poprawiających jakość życia.

\section{Rak pęcherza moczowego Dane epidemiologiczne}

W Polsce w latach 1980-2013 nastąpił prawie czterokrotny (z 1402 do 5390) wzrost liczby rozpoznań raka pęcherza moczowego u mężczyzn i sześciokrotny (z 268 do 1575) u kobiet. Prawdopodobieństwo zgonu w grupach mężczyzn i kobiet wzrosło w okresie 1965-2013 ponad czterokrotnie (odpowiednio — z 633 do 2686 i z 167 do 727 [2].

W porównaniu z innymi krajami Unii Europejskiej umieralność na raka pęcherza moczowego w Polsce jest wyższa. W 2009 roku współczynnik umieralności mężczyzn był o około 50\% wyższy niż średni dla krajów UE. U kobiet umieralność jest nieznacznie wyższa niż średnia dla Europy [26].

Wskaźnik 5-letnich przeżyć względnych u chorych na nowotwory pęcherza moczowego w Polsce w okresie od 2000 r. do 2002 r. i od 2003 r. do 2005 r. w grupie mężczyzn wynosił odpowiednio $57,1 \%, 61,4 \%$, a w grupie kobiet $59,8 \%, 65,1 \%$ [2].

\section{Rozpoznanie}

W omawianym okresie wprowadzono nowe metody obrazowania guza pęcherza w trakcie badania endoskopowego. Są to: diagnostyka fotodynamiczna (PDD — photodynamic diagnosis) oraz obrazowanie w wąskim paśmie światła (NBI — narrow band imaging).

PDD wykonywana jest z wykorzystaniem fioletowego światła po wcześniejszym dopęcherzowym podaniu fotouczulacza (kwasu 5-aminolewulinowego, ALA lub kwasu heksaaminolewulinowego, HAL). Przeprowadzając badanie techniką NBI, wykorzystuje się filtry optyczne, dzięki którym można łatwiej zaobserwować patologiczne unaczynienie raka pęcherza moczowego w porównaniu do obrazu uzyskiwanego w świetle białym.

Wprowadzono też do użytku testy pozwalające wykrywać molekularne markery raka pęcherza moczowego w moczu (np. BTA czy NMP22). Czułość i swoistość tych testów nie pozwala jednak na zastąpienie cystoskopii [26].

\section{Leczenie}

W okresie 25 lat nie wprowadzono nowych sposobów postępowania, które w sposób istotny wpłynęłyby 
na wyniki leczenie raka nienaciekającego i naciekającego mięśniówkę. W wyspecjalizowanych ośrodkach radykalne zabiegi u chorych na raka pęcherza moczowego naciekającego mięśniówkę wykonuje się metodą laparoskopową lub w asyście robota, jednak zgodnie z aktualnymi wytycznymi Europejskiego Towarzystwa Urologicznego standardem jest nadal operacja „otwarta" [26].

Pomimo ponoszenia coraz większych kosztów na zapobieganie, rozpoznawanie i leczenie tego nowotworu wyniki leczenia nie zmieniły się w ciągu ostatnich 25 lat.

Leczenie raka pęcherza pozostaje jednym z najbardziej kosztochłonnych aspektów urologii onkologicznej, niezależnie od kraju.

Wyniki leczenia raka pęcherza moczowego w Polsce są bardzo złe [25].

\section{Podsumowanie}

W okresie ostatniego ćwierćwiecza możliwości rozpoznawania oraz wyniki leczenia raka pęcherza moczowego z nabłonka przejściowokomórkowego nie uległy zasadniczej zmianie.

\section{Rak nerki \\ Dane epidemiologiczne}

W Polsce w latach 1980-2013 nastąpił czterokrotny wzrost liczby rozpoznań raka nerki u mężczyzn (z 713 do 3111) i u kobiet (z 462 do 2032). Prawdopodobieństwo zgonu w okresie 1965-2013 u mężczyzn wzrosło prawie siedem razy (z 243 do 1611), a u kobiet prawie sześć razy (z 165 do 973) [2, 27].

W 2009 roku współczynnik umieralności wśród mężczyzn był o około 25\% wyższy niż średni dla krajów Unii Europejskiej, a wśród kobiet — nieznacznie wyższy. Wskaźnik 5-letnich przeżyć względnych w Polsce w okresie 2000-2002 i 2003-2005 u mężczyzn wynosił odpowiednio 52,1\%, $54,6 \%$, a u kobiet $-57,1 \%$ i $62,4 \%[2,27]$.

\section{Rozpoznanie}

Wzrost dostępności badań obrazowych, a w szczególności upowszechnienie badania USG jamy brzusznej, tomografii komputerowej i rezonansu magnetycznego, sprawił, że obecnie ponad 50\% guzów nerek wykrywanych jest przypadkowo w trakcie diagnostyki innych chorób. Wprowadzenie do diagnostyki medycznej obrazowania w trzech wymiarach bardzo ułatwiło planowanie (zakres leczenia chirurgicznego) oraz przeprowadzenie zabiegu.

\section{Leczenie}

Przed 25 laty standardem postępowania w przypadku raka, niezależnie od lokalizacji i wielkości zmiany, było usunięcie całej nerki. Zwykle nie czyniono tego, gdy rozpoznawano uogólnioną chorobę nowotworową (stadium M1).
Zgodnie z obecnie obowiązującymi wytycznymi Europejskiego Towarzystwa Urologicznego (EAU) z 2015 r. w przypadku guza nerki o rozmiarach do $4 \mathrm{~cm}$ oraz gdy guz ma rozmiary pomiędzy 4-7 cm i jest "korzystnie” zlokalizowany, rekomendowana jest częściowa nefrektomia (NSS - nephron sparing surgery).

Udowodniono, że jeżeli guz usuwany jest w granicach zdrowych tkanek (resekcja R0), przeżycie całkowite, przeżycie zależne od nowotworu i przeżycie bez wznowy choroby jest takie samo, jak po radykalnej nefrektomii. Zaletą postępowania oszczędzającego narząd jest lepsze zachowanie funkcji nerki [28].

W ostatnich latach wprowadzono małoinwazyjne metody, które znacznie zmniejszyły stres okołooperacyjny chorego oraz skróciły do minimum (1-2 dni) okres pobytu w szpitalu. Są to zabiegi laparoskopowe i z wykorzystaniem robota. Obecne wytyczne EAU zalecają, by radykalne usunięcie nerki, jeśli już jest niezbędne, było wykonywane metodą laparoskopową, a nie otwartą [28].

Do kolejnych osiągnięć należy zaliczyć minimalizację sprzętu endoskopowego (giętkie cystoskopy, ureterorenoskopy). Zaletami obecnie stosowanego sprzętu endoskopowego są: małe rozmiary, łatwość obsługi oraz bardzo dobry (trójwymiarowy) obraz oglądanego narządu. Wadą jest wysoka cena.

W ostatnich latach nastąpił rozwój metod ablacyjnych, które mogą stanowić alternatywę dla leczenia operacyjnego chorych, którzy nie kwalifikują się leczenia chirurgicznego np. z powodu licznych obciążeń internistycznych lub tych, u których leczenie chirurgiczne wiązałoby się z koniecznością obustronnej nefrektomii (i dializoterapii). W tych sytuacjach pacjenci mogą być kwalifikowani do krioablacji lub ablacji termicznej z wykorzystaniem fal o częstotliwości radiowej (RFA — radiofrequency ablation). Aplikatory różnego rodzaju energii wprowadza się w tkankę guza pod kontrolą wzroku, ultrasonografu lub tomografu komputerowego. Odległe wyniki leczenia metodami ablacyjnym nie są jeszcze ocenione.

W Polsce, z powodu małych nakładów finansowych na zakup nowych technologii medycznych, dostęp do nich w leczeniu chorych na nowotwory nerek jest ograniczony.

Poznanie molekularnych podstaw rozwoju raka nerki umożliwiło wprowadzenie nowych leków, które stosuje się w uogólnionym raku jasnokomórkowym (mRCC - metastatic renal cell carcinoma). Współczesne leczenie systemowe raka nerki ma charakter "celowany". Leki te w zależności od mechanizmu działania można podzielić na: inhibitory kinaz tyrozynowych, przeciwciała monoklonalne przeciwko VEGF czy inhibitory mTOR, które spowalniają progresję choroby ingerując m.in. w proces neoangiogenzy. Przed rozpoczęciem terapii celowanej wykonuje się cytoredukcyjną nefrektomię. Udowodniono, że ten schemat postępowania wydłuża czas przeżycia wolnego od progresji i/lub czas przeżycia całkowitego u chorych na mRCC [28-30]. 


\section{Podsumowanie}

Ponad 50\% rozpoznawanych obecnie raków nerki to zmiany małe, bezobjawowe i przypadkowo wykrywane. Jeśli zostaną radykalnie usunięte, rokowanie jest zwykle dobre.

\section{Nowotwór zarodkowy jądra Dane epidemiologiczne}

Nowotwór zarodkowy jądra jest najczęstszym nowotworem złośliwym rozpoznawanym u młodych mężczyzn (20-44 lata). W Polsce w latach 1980-2013 nastąpił prawie czterokrotny wzrost liczby zachorowań (z 328 do 1155). Liczba zgonów zwiększyła się w latach 1965-2013 z 71 do 127 rocznie. Umieralność w Polsce była nieco wyższa niż przeciętna dla krajów Unii Europejskiej. Wskaźniki 5-letnich przeżyć względnych w Polsce w latach 2000-2002 i 2003-2005 wynosiły odpowiednio $87,7 \%$ i $87,6 \%[2,31]$.

\section{Rozpoznanie}

W okresie ostatnich 25 lat rola markerów nowotworowych (alfa-fetoproteina, podjednostka beta choriongonadotropiny, dehydrogenaza mleczanowa) i badań obrazowych (CT, MRI) powszechnie stosowanych w rozpoznaniu, monitorowaniu skuteczności leczenia i kontrolowaniu wyleczonych z choroby nowotworowej mężczyzn pozostała bez zmian. Badanie PET stało się pomocne w ocenie skuteczności leczenia nasieniaków [33].

\section{Leczenie}

Bardzo dobre wyniki leczenia nowotworów zarodkowych jądra wpłynęły na zainteresowanie klinicystów poprawą szeroko definiowanej jakości życia rosnącej populacji młodych mężczyzn wyleczonych z choroby nowotworowej. Do istotnych problemów, które należy pilnie rozwiązać należą:

- zaburzenia metaboliczne związane z hypogonadyzmem, np. nadciśnienie tętnicze, zaburzenia lipidowe, otyłość, zaburzenia metabolizmu glukozy, ryzyko incydentów sercowo-naczyniowych czy zmniejszenie masy kostnej [34],

- zwiększone ryzyko nowotworów indukowanych leczeniem (second malignant neoplasm, SMN) - ryzyko litego SMN jest tym większe, im w młodszym wieku było zastosowane leczenie nzj (chemioterapia i/lub radioterapia).Współcześnie stosowana chemioterapia z użyciem cisplatyny jest związana z 40-procentowym wzrostem ryzyka zachorowania na lity SMN [35]. Po zakończeniu chemioterapii opisywane jest również zwiększone ryzyko wystąpienia białaczek, głównie ostrej białaczki szpikowej. Ryzyko to jest uzależnione od dawki całkowitej cisplatyny i etopozydu [36],

- inne odległe następstwa leczenia: pneumotoksyczność (głównie po bleomycynie), nefro-, oto- i neurotoksyczność (głównie w wyniku leczenia cisplatyną).
Istotnym zagadnieniem po skutecznym leczeniu jest posiadanie zdrowego potomstwa. Problemem pozostaje jakość nasienia po leczeniu, możliwość przechowania pobranego przed leczeniem nasienia (w tzw. kriobankach), które po zakończeniu leczenia można wykorzystać, stosując coraz bardziej skuteczne „techniki pozaustrojowego rozrodu". Niestety, system ochrony zdrowia w naszym kraju nie jest przygotowany do rozwiązania istotnych problemów rosnącej populacji młodych mężczyzn wyleczonych z choroby nowotworowej.

\section{Podsumowanie}

W Polsce w ciągu 25 lat nastąpił istotny wzrost zachorowalności na nowotwory zarodkowe jądra u młodych mężczyzn, przy utrzymujących się bardzo dobrych wynikach leczenia. Rola radioterapii zmniejsza się z powodu ryzyka rozwoju kolejnego nowotworu. Wyzwaniem jest zapobieganie powikłaniom zastosowanego leczenia w stale wzrastającej populacji młodych mężczyzn wyleczonych z choroby nowotworowej.

Konflikt interesów: nie zgłoszono

\section{Lek. Paweł Stajno}

Klinika Nowotworów Układu Moczowego

Centrum Onkologii — Instytut im. Marii Skłodowskiej-Curie w Warszawie

ul. Roentgena 5, 02-781 Warszawa

e-mail:stajno.p@wp.pl

\section{Piśmiennictwo}

1. Krajowy Rejestr Nowotworów - http://onkologia.org.pl/nowotwory-zlosliwe-gruczolu-krokowego-c61.

2. Didkowska J, Wojciechowska U. Nowotwory złośliwe w Polsce w 2013 r. Warszawa: Centrum Onkologii — Instytut im. Marii Skłodowskiej-Curie, 2005

3. Mottet N, Bellmunt J, Briers E i wsp. Guidelines on Prostate Cancer - European Association of Urology Guidelines - 2015. https://uroweb. org/wp-content/uploads/09-Prostate-Cancer_LR.pdf.

4. Turkbey B, Pinto PA, Mani $\mathrm{H}$ i wsp. Prostate cancer: value of multiparametric MR imaging at $3 \mathrm{~T}$ for detection-histopathologic correlation. Radiology 2010; 255: 89-99.

5. Calabria F, Rubello D, Schillaci O. The optimal timing to perform 18F/11C-choline PET/CT in patients with suspicion of relapse of prostate cancer: trigger PSA versus PSA velocity and PSA doubling time. Int $J$ Biol Markers 2014; 29: e423-30.

6. Zamboglou C, Wieser G, Hennies Si wsp. MRI versus 68Ga-PSMA PET/CT for gross tumour volume delineation in radiation treatment planning of primary prostate cancer. Eur J Nucl Med Mol Imaging 2016; 43: 889-897.

7. Birkhäuser FD, Studer UE, Froehlich JM i wsp. Combined ultrasmall superparamagnetic particles of iron oxide-enhanced and diffusion-weighted magnetic resonance imaging facilitates detection of metastases in normal-sized pelvic lymph nodes of patients with bladder and prostate cancer. Eur Urol 2013; 64: 953-960.

8. Deras IL, Aubin SM, Blase A i wsp. PCA3: a molecular urine assay for predicting prostate biopsy outcome. J Urol 2008; 179: 1587-1592.

9. Ling CC, Yorke E, Fuks Z. From IMRT to IGRT: frontierland or neverland? Radiother Oncol 2006; 78: 119-122.

10. Rees J, Patel B, Macdonagh R i wsp. Cryosurgery for prostate cancer. BrJUrol Int 2004; 93: 710-714.

11. Poissonnier L, Chapelon JY, Rouvière O i wsp. Control of prostate cancer by transrectal HIFU in 227 patients. Eur Urol 2007; 51: 381-387. 
12. Fizazi K, Scher HI, Molina A i wsp. Abiraterone acetate for treatment of metastatic castration-resistant prostate cancer: final overall survival analysis of the COU-AA-301 randomised, double-blind, placebo-controlled phase 3 study. Lancet Oncol 2012; 13: 983-992.

13. Ryan CJ, Smith MR, de Bono JS. Abiraterone in metastatic prostate cancer without previous chemotherapy. N Engl J Med 2013; 368: 138-148.

14. Beer TM, Armstrong AJ, Rathkopf DE i wsp. Enzalutamide in metastatic prostate cancer before chemotherapy. NEngl J Med 2014; 371:424-433.

15. Sternberg CN, de Bono JS, Chi KN i wsp. Improved outcomes in elderly patients with metastatic castration-resistant prostate cancer treated with the androgen receptor inhibitor enzalutamide: results from the phase III AFFIRM trial. Ann Oncol 2014; 25: 429-434.

16. Petrylak DP, Tangen CM, Hussain MH i wsp. Docetaxel and estramustine compared with mitoxantrone and prednisone for advanced refractory prostate cancer. New Engl J Med 2004; 351: 1513-1520.

17. Tannock IF, de Wit R, Berry WR i wsp. Docetaxel plus prednisone or mitoxantrone plus prednisone for advanced prostate cancer. New Engl J Med 2004; 351: 1502-1512.

18. Kantoff PW, Higano CS, Shore ND i wsp. Sipuleucel-T immunotherapy for castration-resistant prostate cancer. NEnglJMed 2010; 363:411-422.

19. Smith MR, Saad F, Coleman R i wsp. Denosumab and bone-metastasis-free survival in men with castrationresistant prostate cancer: results of a phase 3, randomised, placebo-controlled trial. Lancet 2012;379:39-46.

20. Parker $C$, Nilsson S, Heinrich D i wsp. Alpha emitter radium-223 and survival in metastatic prostate cancer. NEng/ J Med 2013; 369: 213-223.

21. http://www.cancer.org/cancer/prostatecancer/detailedguide/prostate-cancer-key-statistics.

22. http://eco.iarc.fr/eucan/CancerOne.aspx?Cancer=29\&Gender=1.

23. Schröder FH, Hugosson J, Roobol MJ i wsp. Screening and prostate cancer mortality: results of the European Randomised Study of Screening for Prostate Cancer (ERSPC) at 13 years of follow-up. Lancet 2014; 384: 2027-2035.

24. Andriole GL1, Crawford ED i wsp. Prostate cancer screening in the randomized Prostate, Lung, Colorectal, and Ovarian Cancer Screening Trial: mortality results after 13 years of follow-up. J Natl Cancer Inst 2012; 104: 125-132.
25. Krajowy Rejestr Nowotworów: http://onkologia.org.pl/nowotwory-zlosliwe-pecherza-moczowego-c67.

26. Babjuk M, Böhle A, Burger M i wsp. Guidelines on non-muscle-invasive bladder cancer (Ta, T1 and CIS) - European Association of Urology Guidelines - 2015, https://uroweb.org/wp-content/uploads/EAUGuidelines-Non-muscle-invasive-Bladder-Cancer-2015-v1.pdf.

27. Krajowy Rejestr Nowotworów: http://onkologia.org.pl/nowotwory-zlosliwe-nerki-c67/.

28. Ljungberg B, Bensalah K, Bexi A i wsp. Guidelines on renal cell carcinoma - European Association of Urology Guidelines - 2015, http:// uroweb.org/wp-content/uploads/10-Renal-Cell-Carcinoma_LR.pdf.

29. Heng DY, Xie W, Regan MM i wsp. Prognostic factors for overall survival in patients with metastatic renal cell carcinoma treated with vascular endothelial growth factor-targeted agents: results from a large, multicenter study. J Clin Oncol 2009; 27: 5794-5799.

30. Négrier S, Gravis G, Pérol D i wsp. Temsirolimus and bevacizumab, or sunitinib, or interferon alfa and bevacizumab for patients with advanced renal cell carcinoma (TORAVA): a randomised phase 2 trial. Lancet Oncol 2011; 12:673-680.

31. Krajowy Rejestr Nowotworów: http://onkologia.org.pl/nowotwory-zlosliwe-jadra-c62/.

32. Albers P, Albrecht W, Algaba F i wsp. Guidelines on Testicular Cancer European Association of Urology Guidelines - 2015, http://uroweb. org/wp-content/uploads/11-Testicular-Cancer_LR1.pdf.

33. De Santis M, Becherer A, Bokemeyer C i wsp. 2-18fluoro-deoxy-D-glucose positron emission tomography is a reliable predictor for viable tumor in postchemotherapy seminoma: an update of the prospective multicentric SEMPET trial. J Clin Oncol 2004; 22: 1034-1039.

34. Wiechno P, Demkow T, Kubiak K i wsp. The quality of life and hormonal disturbances in testicular cancer survivors in cisplatin era. Eur Urol 2007; 52: 1448-1454.

35. Fung C, Fossa SD, Milano MT i wsp. Solid tumors after chemotherapy or surgery for testicular nonseminoma: a population-based study. J Clin Oncol 2013; 31: 3807-3814.

36. Howard R, Gilbert E, Lynch CF i wsp. Risk of leukemia among survivors of testicular cancer: a population-based study of 42,722 patients. Ann Epidemiol 2008; 18: 416-421. 